\title{
Penerapan Metode Eksperimen untuk Meningkatkan Hasil Belajar Siswa Pada Materi Pesawat Sederhana Kelas V SD
}

\author{
Rohayati \\ SDN Citepus 01 \\ rohayati5538@gmail.com
}

\section{Article History}

received $3 / 12 / 2020$

\begin{abstract}
The problem of this research is the students' learning outcomes in the science subject of simple aircraft for class V SD Negeri Citepus 01 in the 2015/2016 academic year. The purpose of this study is to improve student learning outcomes. This research was conducted in 2 cycles consisting of planning, implementation, observation and reflection. The subjects of this study were the fifth grade students of SD Negeri Citepus 01, totaling 35 students. The technique of collecting the results of the short and descriptive test results. Data analysis was carried out by analyzing quantitatively and qualitatively, to find out whether or not student learning was complete or not. Based on the learning outcomes from the pre-cycle, cycle I and cycle II experienced a significant increase. In the pre-cycle learning outcomes were $43 \%$ and increased in the first cycle by $69 \%$, while the second cycle increased even more, namely learning outcomes reached $91 \%$. The conclusion of this study is that the application of the experimental method can improve the learning outcomes of fifth graders at SDN Citepus 01 in science subjects about simple machines.
\end{abstract}

Keywords: experimental method, learning outcomes, simple machine

\begin{abstract}
Abstrak
Permasalahan penelitian ini adalah hasil belajar siswa pada mata pelajaran IPA materi pesawat sederhana kelas V SD Negeri Citepus 01 tahun pelajaran 2015/2016. Tujuan penelitian ini adalah meningkatkan hasil belajar siswa. Penelitian ini dilaksanakan dalam 2 siklus yang terdiri atas perencanaan, pelaksanaan, observasi dan refleksi. Subjek penelitian ini adalah siswa kelas V SD negeri Citepus 01 yang berjumlah 35 siswa. Teknik pengumpulan dari hasil tes isian singkat dan uraian. Analisis data dilakukan dengan menganalisis kuantitatif dan kualitatif, untuk mengetahui tuntas atau tidak tuntasnya belajar siswa. Berdasarkan hasil belajar dari prasiklus, siklus I dan siklus II mengalami peningkatan yang cukup signifikan. Pada prasiklus hasil belajar $43 \%$ dan mengalami peningkatan pada siklus I sebesar $69 \%$, sedangkan siklus II lebih meningkat lagi yaitu hasil belajar mencapai $91 \%$. Simpulan penelitian ini adalah penerapan metode eksperimen dapat meningkatkan hasil belajar siswa kelas V SDN Citepus 01 pada mata pelajaran IPA tentang pesawat sederhana.
\end{abstract}

Kata kunci: metode eksperimen, hasil belajar, pesawat sederhana

Social, Humanities, and Education Studies (SHEs): Conference Series https://jurnal.uns.ac.id/shes

p-ISSN 2620-9284 e-ISSN 2620-9292 


\section{PENDAHULUAN}

Pendidikan sangat penting dan dibutuhkan oleh setiap orang tanpa kecuali, baik itu yang kaya, miskin, tua, muda, besar maupun kecil. Telah dijelaskan dalam undangundang No. 20 Tahun 2003 tentang Sistem Pendidikan Nasional Pasal 1 ayat 1 bahwa pendidikan adalah usaha sadar untuk menciptakan suasana belajar dan proses pembelajaran agar peserta didik secara aktif mengembangkan potensi dirinya untuk memiliki kekuatan spiritual keagamaan, pengendalian diri, kepribadian, kecerdasan, akhlak mulia, serta ketrampilan yang diperlukan oleh dirinya, masyarakat bangsa dan negara. Peserta didik merupakan komponen yang melakukan kegiatan belajar untuk mengembangkan potensi kemampuan menjadi nyata guna mencapai tujuan belajar. (Hamruni,2012: 11). Maka sudah menjadi tugas kita sebagai pendidik untuk membantu mewujudkan proses pembelajaran yang ideal bagi peserta didik agar potensi yang dimiliki dapat berkembang secara optimal. Menurut Sri Anitah (2011:2.3) menyatakan bahwa belajar adalah menambah dan mengumpulkan pengetahuan untuk menjadi pintar atau membentuk intelektual, sedangkan sikap dan keterampilan diabaikan.

Sedangkan menurut Santrock dan Yusen (1994) menyatakan "learning is defined as relatively permanent change in behavior that occurs through experience.". Belajar didefinisikan sebagai perubahan tingkah laku yang terjadi karena pengalaman (Taufiq, A. 2014: 5.4).

IPA merupakan salah satu mata pelajaran wajib yang di ujikan dalam ujian nasional. Pembelajaran IPA disekolah dasar selalu mengacu pada kurikulum IPA. Dalam pembelajaan IPA harus menekankan pada penguasaan kompetensi melalui serangkaian proses ilmiah. Maka dalam hal ini diperlukan strategi pembelajaran yang tepat untuk menanamkan konsep - konsep IPA. Seorang guru dalam mengajar tidak hanya sekedar mentransfer ilmu, tapi juga harus membuat pembelajaran itu menjadi lebih bermakna.

Mata pelajaran IPA diberikan kepada peserta didik mulai dari tingkat sekolah dasar untuk membekali peserta didik dengan kemampuan berpikir logis, realistis, sistematis, kritis, kreatif, inovatif, dapat mendeskripsi gejala alam dan sosial dan kerja sama.

Pendidikan hendaknya dibawa ke kondisi ideal, namun dalam kenyataan dilapangan berbeda. Hal ini dapat dilihat pada hasil pembelajaran IPA SD Negeri Citepus 01 kelas V tentang Pesawat Sederhana Tahun ajaran 2015/2016.

Berdasarkan pengamatan diperoleh hasil motivasi serta belajar siswanya masih kurang. Dari 35 siswa yang terdiri dari 16 siswa laki-laki dan 19 siswa perempuan, hanya 12 siswa yang termotivasi (34\%) dan 23 siswa (66\%) belum termotivasi. Sedangkan nilai tes formatifnya yaitu dari keseluruhan peserta didik yang terdiri dari 35 siswa, baru 15 siswa (43\% siswa) yang memperoleh nilai diatas Kriteria Ketuntasan Minimal (KKM) dan 20 siswa (57\%) hasil belajarnya belum maksimal atau masih dibawah standar KKM yang telah ditetapkan yaitu 70 .

Berdasarkan hasil observasi, rendahnya nilai hasil belajar siswa kelas V SD Negeri Citepus 01 disebabkan oleh beberapa faktor antara lain : metode yang diterapkan di sekolah lebih sering menggunakan metode ceramah, guru jarang menggunakan alat peraga, siswa kurang dilibatkan dalam pembelajaran, siswa lebih banyak duduk, diam, sehingga hanya terjadi komunikasi satu arah. Belum terjadi pembelajaran interaktif. Oleh karena itu metode ini akan lebih baik jika diubah dengan metode yang dapat melibatkan siswa secara aktif dalam proses belajar mengajar.

Berdasarkan hal tersebut peneliti memandang perlu diadakannya perubahan pendekatan pembelajaran dan perbaikan pembelajaran untuk meningkatkan pemahaman siswa agar mencapai hasil yang optimal. Perbaikan itu peneliti lakukan dengan menggunakan metode eksperimen. Pengertian Metode menurut Hamruni, (2012:12) adalah cara yang digunakan untuk mencapai tujuan pembelajaran yang 
telah ditetapkan Peneliti memilih menggunakan metode eksperimen. Mengacu pada teori Jean Piaget yang mengatakan bahwa cara berpikir seseorang berkembang secara bertahap atau beberapa periode. Menurut Piaget seorang anak bukanlah seperti tabung yang menanti untuk diisi dengan pengetahuan, melainkan secara aktif anak akan membangun pengetahuan tentang dunia dan isinya melalui keterlibatannya atau hubungan dengannya (Sapriati,A.2011:1.4).

Berdasarkan fakta dan latar belakang masalah yang ada diatas bisa dikatakan adanya masalah yang terjadi dalam pembelajaran tersebut, antara lain : Motivasi belajar siswa yang masih rendah pada pelajaran IPA dan Hasil belajar siswa yang masih rendah.Beberapa masalah yang terjadi dalam pembelajaran IPA,yaitu:siswa kurang tertarik pada pelajaran IPA,siswa menganggap IPA pelajaran yang membosankan,guru jarang menggunakan alat peraga. Berdasarkan latar belakang masalah diatas yang menjadi fokus perbaikan pembelajaran dalam penelitian materi "pesawat sederhana" adalah sebagai berikut :" Bagaimana meningkatkan hasil belajar siswa tentang pesawat sederhana melalui penerapan metode eksperimen pada siswa kelas V SD Negeri Citepus 01 tahun pelajaran 2015/ 2016?"

Untuk dapat mengetahui penyebab adanya masalah perlu dilakukan analisis masalah dan diprediksi adanya beberapa kemungkinan yang menjadi faktor penyebab rendahnya motivasi dan hasil belajar siswa, yaitu:Metode yang digunakan guru kurang menarik dalam pembelajaran,guru kurang mampu menciptakan pembelajaran yang efektif untuk membangkitkan motivasi belajar siswa,kurangnya media dan alat peraga yang digunakan dalam pembelajaran

Beberapa penelitian yang relevan diantaranya "Penerapan Metode Eksperimen untuk Meningkatkan Hasil Belajar IPA Siswa Kelas V SD" karya Somantri dkk ( 2018 ) dan "Upaya Peningkatan Hasil Belajar IPA Melalui Metode Eksperimen dengan Berbantuan Media Visual Pada Siswa Kelas IV SD Negeri 4 Bandungharjo Kecamatan Toroh Semester II Tahun Ajaran 2015/2016" karya Karolina Ayu Sianturi. Dalam penelitian tersebut dijelaskan bahwa kemampuan siswa dalam pelajaran IPA masih sangat rendah karena guru hanya menggunakan metode ceramah. Dari masalah tersebut peneliti kemudian mencoba menerapkan metode eksperimen dalam proses pembelajaran. Dari hasil tes siklus I terdapat peningkatan yang signifikan kemudian dilanjutkan dengan siklus II hasil lebih maksimal. Ternyata penggunaan metode eksperimen cukup signifikan untuk mendongkrak nilai/hasil belajar siswa.

Berdasarkan pertimbangan diatas, peneliti memilih menggunakan metode eksperimen yang sesuai dengan perkembangan kognitif dan dapat meningkatkan motivasi dan hasil belajar siswa kelas V SD Negeri Citepus 01. Menurut Hasan Alwi (2005: 290) menjelaskan bahwa metode eksperimen yakni percobaan yang bersistem dan terencana untuk membuktikan kebenaran akan suatu teori. Sedangkan menurrut Roestiyah, (2012: 80), pengertian Meteode eksperimen merupakan satu dari banyak metode mengajar di mana siswa melaksanakan sesuatu percobaan mengenai sesuatu hal, melihat prosesnya dan menuliskan hasil percobaannya, selanjutnya hasil pengamatan tersebut disampaikan di kelas dan dievaluasi oleh pendidik. Diharapkan dengan menggunakan metode eksperimen dapat meningkatkan kemampuan serta peran siswa dalam belajar, dan meningkatkan kemampuan akademik melalui aktifitas belajar kelompok dan melakukan eksperimen.

\section{METODE}

Penelitian ini adalah penelitian tindakan kelas (Classroom Action Research) dengan menerapkan metode eksperimen. Menurut Kurt Lewin dalam Kunandar (2011: 42) penelitian tindakan kelas ini terdiri dari empat tahapan dasar yaitu perencanaan (planning), pelaksanaan (acting), pengamatan (observing) dan refleksi (reflecting). Analisis penelitian ini adalah analisis deskriptif kuantitafif kualitatif dimana dalam penelitian ini selain penyajian hasil berupa data maupun angka peneliti juga 
menentukan bagaimana cara pengolahan hasil penelitian yakni dengan membuat analisisnya dengan menerapkan metode eksperimen. Penelitian ini dilaksanakan pada peserta didik kelas V SD Negeri Citepus 01 Tahun Pelajaran 2015/2016. Penelitian dilaksanakan dalam 2 siklus, masing-masing siklus dilaksanakan 2 kali pertemuan, 1 x pertemuan menggunakan waktu $2 \times 35$ menit. Pelaksanaan perbaikan siklus I pertemuan kesatu yaitu pada Rabu, 28 Oktober 2015 dan Pertemuan kedua Sabtu, 31 Oktober 2015. Pelaksanaan perbaikan Siklus II pertemuan kesatu yaitu Rabu, 11 November 2015 dan pertemuan kedua pada Sabtu, 14 November 2015. Teknik pengumpulan data yang dilakukan dengan observasi dan tes, baik pre test maupun post test. Observasi meliputi observasi keterlaksanaan metode eksperimen, dalam proses pembelajaran. Untuk hasil belajar menggunakan tes secara tertulis

\section{HASIL DAN PEMBAHASAN}

Berdasarkan rumusan hipotesis, peneliti membuat Rencana Pelaksanaan Perbaikan Pembelajaran beserta skenario tindakan yang akan dilakukan dalam kegiatan perbaikan pembelajaran. Kompetensi Dasar yang dimuat agar siswa dapat menguasai materi pesawat sederhana. Sehubungan dengan Rencana Pelaksanaan Perbaikan Pembelajaran (RPPP), peneliti mempersiapkan berbagai bahan yang diperlukan seperti alat untuk praktek, bahan diskusi, media pembelajaran,alat bantu pembelajaran (berupa soal evaluasi), dan lembar observasi untuk observer. Selanjutnya bersama teman sejawat yang bertugas sebagai observer, menyepakati hal-hal yang berkaitan dengan kelancaran observasi, jenis-jenis kegiatan yang harus dilaksanakan dan diobservasi, serta lainnya. Setelah tercapai kesepakatan guru melakukan kegiatan perbaikan pembelajaran.

Pelaksanaan tindakan pada siklus I dengan menggunakan metode eksperimen dilaksanakan dalam dua kali pertemuan dan alokasi waktu 70 menit untuk satu kali pertemuan. Pertemuan pertama dilaksanakan dengan mempraktekkan pesawat sederhana pengungkit jenis pertama (tang, palu, gunting ). Pertemuan kedua dilaksanakan dengan mempraktekkan pengungkit jenis pertama dan bidang miring (pisau, gunting, pembuka tutup botol). Dari hasil tes formatif siswa pada pembelajaran IPA materi pesawat sederhana siklus I, diperoleh data sebagai berikut:

Table 1. Rekapitulasi ketuntasan hasil belajar Siklus I

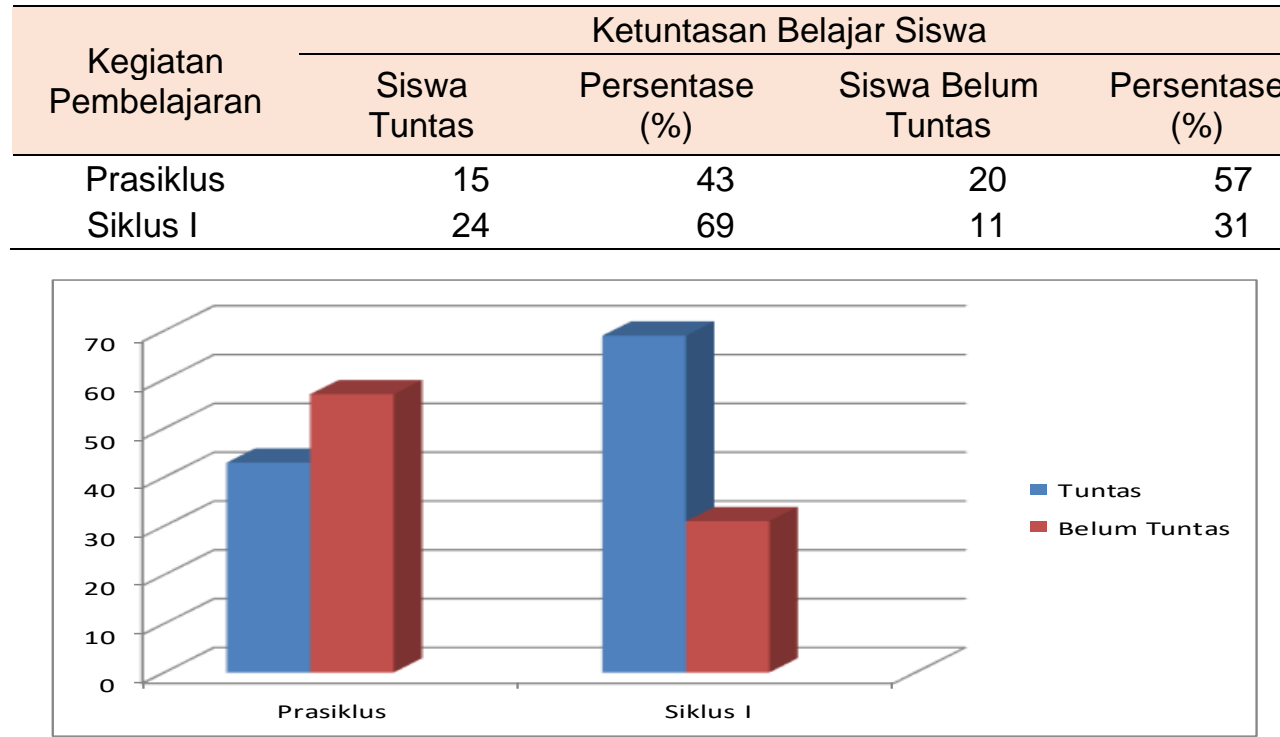

Gambar 1. Diagram Perbandingan Prosentase Ketuntasan Hasil Belajar Kondisi Prasiklus dengan Hasil Siklus I 
Berdasarkan tabel di atas maka terjadi peningkatan hasil belajar antara prasiklus dan siklus 1. Setiap individu peserta didik sudah mengalami peningkatan hasil belajarnya. Peserta didik mengalami peningkatan hasil belajar pada siklus 1 . Ketuntasan klasikal juga mengalami peningkatan, pada prasiklus hanya terdapat 15 anak yang sudah tuntas, tetapi pada siklus 1 bertambah menjadi 24 anak yang sudah tuntas dengan Kriteria Ketuntasan Minimal (KKM) sebesar 70. Persentase ketuntasan klasikalnya meningkat, jika pada pertemuan prasiklus hanya $43 \%$ maka pada siklus 1 menjadi $69 \%$.

Berdasarkan refleksi pada siklus I maka diputuskan untuk melanjutkan ke siklus II dikarenakan belum mencapai ketuntasan klasikal yang diharapkan.Peneliti akan mencoba memperbaiki pada siklus II dengan menyempurnakan tindakan yaitu dengan mengoptimalkan alat peraga (menambah media seperti staples dan pemotong kuku) memaksimalkan waktu yang tersedia, lebih memotivasi siswa dengan lagu,dan menerapkan metode eksperimen lebih baik lagi. Diharapkan terjadi peningkatan, baik peningkatan motivasi belajar siswa maupun hasil belajar siswa. Berikut ini adalah hasil belajar peserta didik pada siklus II yang bisa dilihat pada tabel berikut.

Tabel 2. Rekapitulasi ketuntasan hasil belajar Siklus II

\begin{tabular}{lcccc}
\hline \multirow{2}{*}{$\begin{array}{c}\text { Kegiatan } \\
\text { Pembelajaran }\end{array}$} & \begin{tabular}{c} 
Siswa \\
\cline { 2 - 5 }
\end{tabular} & $\begin{array}{c}\text { Ketuntasan Belajar Siswa } \\
(\%)\end{array}$ & $\begin{array}{c}\text { Siswa Belum } \\
\text { Tuntas }\end{array}$ & Persentase (\%) \\
\hline Prasiklus & 15 & 43 & 20 & 57 \\
Siklus I & 24 & 69 & 11 & 31 \\
Siklus II & 32 & 91 & 3 & 9 \\
\hline
\end{tabular}

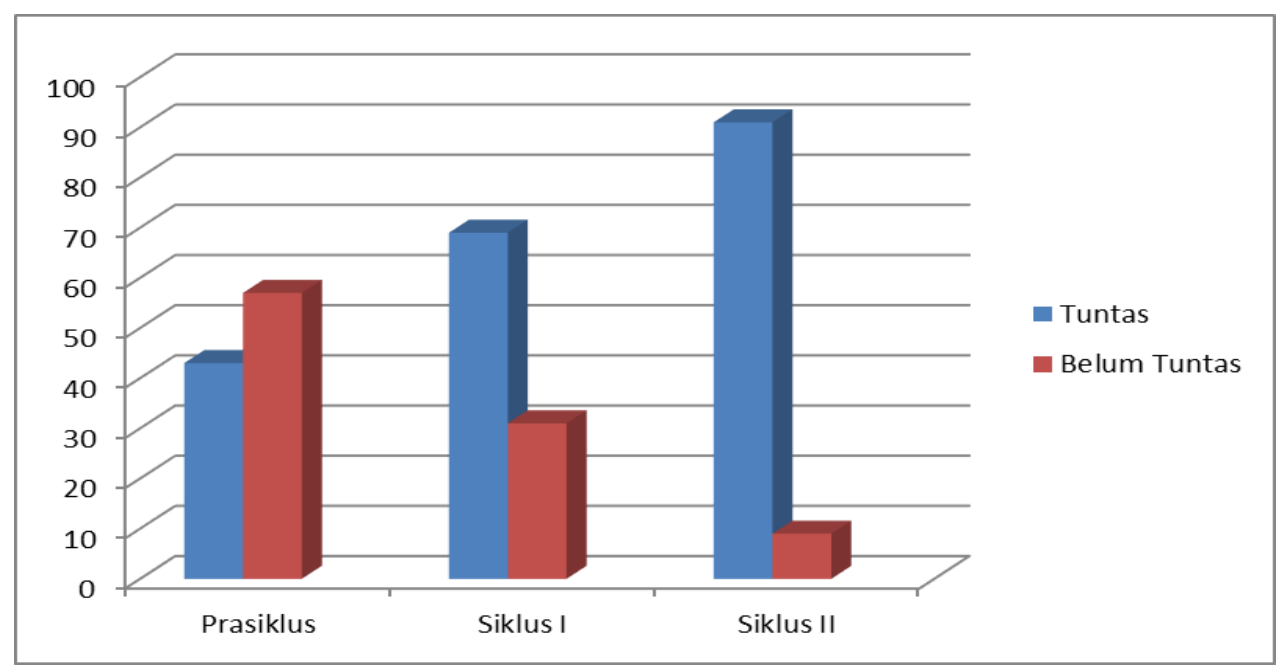

Gambar 2. Diagram Perbandingan Prosentase Ketuntasan Hasil Belajar Kondisi Prasiklus dengan Hasil Siklus I dan Siklus II

Ketuntasan klasikal mengalami peningkatan, pada prasiklus hanya terdapat 15 anak yang sudah tuntas, tetapi pada siklus I bertambah menjadi 24 anak yang sudah tuntas dengan Kriteria Ketuntasan Minimal (KKM) sebesar 70. Demikian juga pada siklus II jumlah peserta didik yang sudah tuntas KKM mengalami peningkatan menjadi 32 peserta didik. Persentase ketuntasan klasikalnya meningkat, jika pertemuan pada siklus I hanya $69 \%$ maka pada Siklus II menjadi 91\%.

Dari dua siklus yang sudah dilaksanakan selama 4 kali pertemuan dapat dipastikan bahwa metode eksperimen dapat meningkatkan hasil belajar peserta didik pada mata pelajaran IPA Kelas V di SD Negeri Citepus 01. Hal ini sesuai dengan konsep atau teori yang diungkap oleh Syaiful Bahri Djamarah (2005: 234) menjelaskan 
bila metode eksperimen merupakan metode yang memberikan kesempatan kepada siswa perorangan atau kelompok untuk berlatih melakukan suatu proses maupun percobaan. Melalui metode ini siswa diharapkan sepenuhnya terlibat eksperimen, melakukan eksperimen, menemukan fakta, mengumpulkan data, mengendalikan variabel, serta memecahkan masalah yang dihadapinya secara nyata. Hasil penelitian ini juga sesuai dengan penelitian sebelumnya yang dilakukan oleh Somantri, dkk (2018) yang membuktikan bahwa metode eksperimen dapat meningkatkan hasil belajar dan kreativitas peserta didik pada pembelajaran IPA.

\section{SIMPULAN}

Penerapan metode eksperimen dapat meningkatkan hasil belajar peserta didik Kelas V pada mata pelajaran IPA materi pesawat sedehana. Penerapan metode eksperimen berhasil karena terjadi peningkatan hasil belajar siswa dari kondisi prasiklus yaitu sebesar $43 \%$ menjadi $69 \%$ di siklus I dan meningkat lagi menjadi $91 \%$ di siklus II. Pencapaian ini telah memenuhi kriteria keberhasilan yang telah ditetapkan yaitu sebesar $85 \%$

Peningkatan yang terjadi karena metode eksperimen membuat siswa lebih percaya diri atas kebenaran atau kesimpulan berdasarkan percobaannya,mampu dalam membina siswa untuk membuat terobosan-terobosan baru dengan penemuan dari hasil percobaannya yang bermanfaat bagi kehidupan manusia serta hasil-hasil percobaan yang berharga dapat dimanfaatkan untuk kemakmuran umat manusia.

Metode eksperimen memberikan kesan pembelajaran yang mendalam bagi peserta didik tehadap materi yang diajarkan melalui setiap langkah - langkah percobaannya. Peserta didik akan selalu teringat akan materi yang diajarkan karena dengan eksperimen siswa menemukan bukti kebenaran dari teori sesuatu yang sedang dipelajarinya.

\section{DAFTAR PUSTAKA}

Anitah, S.W.(2011). Strategi Pembelajaran di SD. Jakarta : Universitas Terbuka.

Djamarah, Drs. Syaiful Bahri, M.Ag. (2005). Guru dan Anak Didik Dalam Interaksi Edukatif Suatu Pendekatan Teoritis Psikologis. Jakarta: Rineka Cipta.

Hamruni. (2012). Strategi Pembelajaran. Yogyakarta: Pustaka Insan Madani.

Hasan Alwi. dkk. 2005. Kamus Besar Bahasa Indonesia. Jakarta: Balai Pustaka.

Kunandar. (2008). Langkah Mudah Penelitian Tindakan Kelas Sebagai Pengembangan Profesi Guru. Jakarta: Rajagrafindo Persada

Republik Indonesia. (2003). Undang-Undang RI Nomor 20, Tahun 2003, tentang Sistem Pendidikan Nasional

Roestiyah. 2001. Strategi Belajar Mengajar. Jakarta: Rineka Cipta

Sapriati, M. dkk. ( 2011 ). Pembelajaran IPA di SD. Jakarta : Universitas Terbuka

Sianturi,K.A (2016 ). Upaya Peningkatan Hasil Belajar IPA Melalui Metode Eksperimen dengan Berbantuan Media Visual Pada Siswa Kelas IV SD Negeri 4 Bandungharjo Kecamatan Toroh Semester II Tahun Ajaran 2015/2016. Retrieved from: https://repository.uksw.edu/handle/123456789/10987

Somatri,dkk. ( 2018 ). Penerapan Metode Eksperimen untuk Meningkatkan Hasil Belajar Siswa Kelas V SD. Retrieved from: https://ejournal.upi.edu/index.php/jpgsd/article/download/14065/8134

Taufiq, A., Mikarsa, H.L., Prianto, P.L. (2014). Pendidikan Anak di SD. Jakarta: Universitas Terbuka. 